\title{
The prediction of personality, culture and coping strategies on university students' psychological help seeking attitudes
}

\author{
İsmail Yelpaze \\ Kahramanmaraş Sütçüimam University, Faculty of Education, Kahramanmaraş, Turkey, \\ ismailyelpaze@gmail.com \\ Aydoğan Aykut Ceyhan (D) \\ Anadolu University, Faculty of Education, Eskişehir, Turkey, aceyhan@ anadolu.edu.tr
}

ABSTRACT This study has attempted to investigate the predictability of university students' personality traits, cultural values, stress coping strategies, negative automatic thoughts and gender on their professional/formal psychological help seeking attitudes. This research has been carried on with the participation of a total of 1284 university students. Predictive correlational method was used. To collect data, valid and reliable measurements were conducted. The hierarchical multiple regression analysis has been used to evaluate the data. As predictors of the psychological help seeking attitude, conscientious and agreeable students have more positive attitudes, but negative-valent and open ones have more negative attitudes. Students who use seeking social support and avoidance stress coping strategies have more positive attitudes, but who use keep-to-self have more negative attitudes. Collectivist and female participants' help seeking attitudes are more positive. With these variables, $14 \%$ of the attitude of seeking psychological help is explained. The findings of the study were associated to Theory of Planned Behavior and discussed in the light of literature.

Keywords: Big five personality, Coping strategies, Help seeking attitudes, Individualistic-collectivistic

\section{Kişilik, kültür ve başa çıkma stratejilerinin üniversite öğrencilerinin psikolojik yardım alma tutumunu yordayıcılığı}

ÖZ Bu çalıșmanın amacı, üniversite öğrencilerinin psikolojik yardım alam tutumları ile kişilik özellikleri, kültürel kimlikleri, başa çıkma stratejileri ve olumsuz otomatik düşünceleri arasındaki ilişkiyi incelemektir. Bu amaç doğrultusunda 1284 üniversite öğrencisinin katılımı ile çalışma nicel desenlerden ilişkisel tarama yöntemi ile yürütülmüştür. Verileri toplamak için geçerlilik-güvenirlik çalışmaları yapılmış ölçme araçları kullanılmış ve verilerin analizinde çoklu doğrusal regresyon analizi yapılmıştır. Bulgulara bakıldığında sorumlu ve uyumlu kişilikteki katılımcıların psikolojik yardım alma konusunda daha olumlu tutuma sahip olduğu, negatif değerli ve yeniliğe açık kişilerin ise olumsuz tutuma sahip oldukları bulunmuştur. Sosyal destek ve kaçınmacı başa çıkmayı kullananların olumlu tutuma sahip oldukları, gizleme davranışı sergileyenlerin olumsuz yardım alam tutumuna sahip oldukları bulunmuştur. Toplulukçu kültürün değerlerini benimseyenler ile kadınların psikolojik yardım alma konusunda olumlu tutum benimsedikleri bulunmuştur. Bu değişkenler ile psikolojik yardım alma tutumunun \% 14'ü açıklanmaktadır. Bulgular literatür ışığında tartı̧̧ılmıştır.

\section{Anahtar Sözcükler: \\ Başa çıkma stratejileri, Beş faktör kişilik, Bireycilik-toplulukçuluk, Psikolojik yardım alma tutumu}

\footnotetext{
Citation:

Yelpaze, İ., \& Ceyhan, A.A. (2020). The prediction of personality, culture and coping strategies on university students' psychological help seeking attitudes. Turkish Journal of Education, 9(2), 134 153. DOI: 10.19128/turje.611402
} 


\section{INTRODUCTION}

Psychological problems affect people's lives as well as physical problems. Complaints about psychological problems, which may sometimes be the cause of physiological disorders, are increasing day by day. According to World Health Organization ("Infographic-Depression in Turkey,", 2017) in European Union (EU) countries, $27 \%$ of the adult population had at least one mental problem last year. In Turkey, $37 \%$ of people applying to primary health care centers suffer from mood disorder, $29 \%$ ones from anxiety disorders, $8.6 \%$ ones from somatoform disorders and $7.7 \%$ ones from possible alcohol abuse (Keskin, Ünlüoğlu, Bilge, \& Yenilmez, 2013) and 4.4. \% ones suffer from depression ("Infographic-Depression in Turkey,", 2017). Due to widespread psychological problems, the government of Turkey has developed several action plans: "Strengthening mental health services with focus on community level, strengthening integration of mental health services / implementation of mhGAP and strengthening mental health services response during emergencies" ("Health Topics,", 2019). Given the results of studies, it is reported that there is a considerable number of individuals experiencing mental/psychological disorders and that some portion of them consists of young adults. Psychological disturbances constitute almost half of the illness burden of young adults (World Health Organization [WHO], 2008), and many psychological illnesses that are life-threatening begin before the age of 24 (Kessler et al., 2005).

The young adulthood is a significant period in which young adults should have various developmental tasks, such as having an identity, establishing romantic relationship, making professional choices and gaining independence. Moreover, the period of young adulthood coincides with the years of university education. The university years are considered to be a stressful period in which students experience emotional, academic, economic, depression, domestic relationships, friend relationships, adaptation, academic and romantic issues (Erkan, Cihangir-Çankaya, Terzi, \& Özbay, 2011; Özgen, 2016; Topkaya \& Meydan, 2013), low self-respect, social anxiety and dissatisfaction with life (Ceyhan, 2009). When such issues are coupled with the feelings of loneliness, homesickness, worry, uncertainty (Dennis, Phinney, \& Chuateco, 2005), selecting courses, exam anxiety, academic competition and assessment, students' lives become more stressful (Perrine \& Lisle, 1995). Being deprived of the parental protection of the previous years (Ültanır, 1998), university students may be in difficulty to deal with multiple issues at once. Especially freshman students who do not have effective coping strategies have difficulty in adapting to university life (Rahat \& İlhan, 2016), so they need help. In this respect, it is vitally important that universities have psychological counseling centers for students to have healthy adaptation process (Güneri, Aydın, \& Skovholt, 2003).

As psychological counseling services have gained importance in the recent years in Turkey, many universities are encouraged to establish psychological counseling centers within their campuses. Almost all universities have a counseling service unless some of them do not have sufficient equipment and personnel. Centers generally employ psychologists, doctors, psychotherapists, psychological counselors and social workers (Mojaverian, Hashimoto, \& Kim, 2013). However, counseling centers at universities are not utilized efficiently. Majority of the studies investigated university students do not consider seeking professional psychological help from counseling services (Koydemir-Özden, DikerCoşkun, Yumurtac1, Erel, \& Şahin, 2009; Topkaya \& Meydan, 2013), or are unwilling to apply to there (Wade, Post, Cornish, Vogel, \& Tucker, 2011). These studies point out the necessity to identify factors that prevent students from applying to psychological counseling services and to come up with solutions regarding this matter.

Studies researching about psychological help seeking are mostly based on Theory of Planned Behavior (TPB). The theory is very effective in determining health-related behaviors. According to TPB, 
subjective norm, perceived behavioral control and attitude together affect intention and indirectly affect behavior. (Ajzen, 1985). Thus, attitude is an important concept of TPB (Figure 1). Even, many studies show that the psychological help seeking attitude, which represents an individual's impression on seeking psychological help in a satisfactory/dissatisfactory manner (Fischer \& Farina, 1995), is an important determinant in identifying individuals' seeking psychological help behavior (Cepeda-Benito \& Short, 1998; Cramer, 1999; Kelly \& Achter, 1995; Sareen et al., 2007; Vogel, Wester, Wei, \& Boysen, 2005). For this reason, identifying factors influencing the help seeking attitude may also indirectly help to reveal information regarding the factors that influence the help seeking behavior. This study aims to determine certain factors (personality trait, cultural values, stress coping strategies, negative automatic thoughts and gender) that can be related to psychological help seeking attitude.

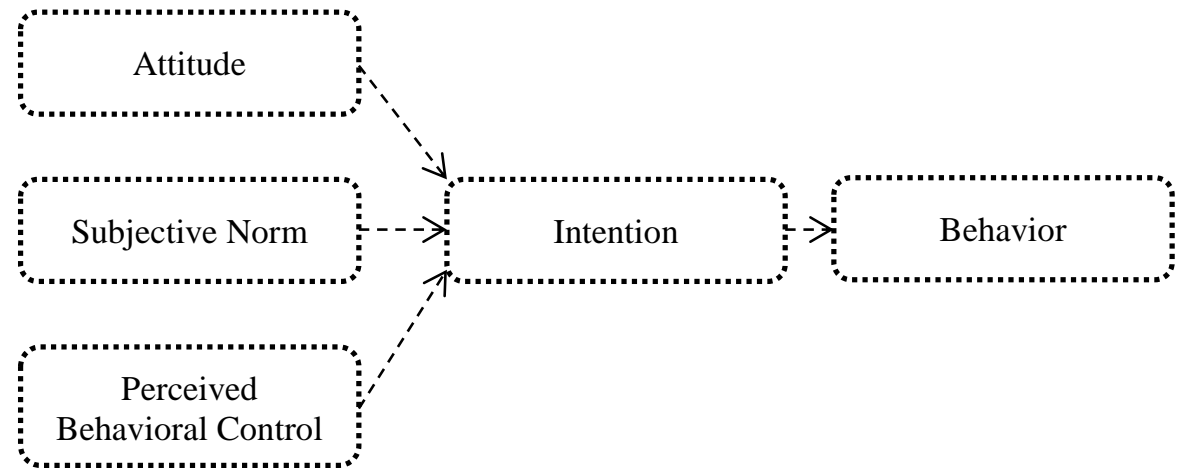

Figure 1. Theory of Planned Behavior (Ajzen, 1991, p.182)

Many factors may play in determining individuals' professional psychological help seeking attitudes. Among such factors, personality traits are likely to be an important determinant. This is because an individual's peculiar and habitual emotions, thoughts, behaviors and attitudes are the manifestations of their personality traits (McCrae \& Costa, 2008; Barenbaum \& Winter, 1999). According to the literature, the studies conducted on personality and psychological help seeking mostly focus on a five-factor personality model. In this respect, it is found that the individuals who possess openness (Atik \& Yalçın, 2011; Kakhnovets, 2011; Özdemir, 2012), agreeableness (Atik \& Yalçın, 2011; Kakhnovets, 2011) and conscientiousness (Kakhnovets, 2011; Özdemir; 2012) demonstrate a more positive help seeking attitudes. The help seeking attitudes of the extrovert and neurotic individuals, however, are found to be negative in some studies (Özdemir, 2012; Şahin-Akaydın, 2002), while they are found to be positive in others (Atik \& Yalçın, 2011; Goodwin, 2008; Kakhnovets, 2011).

In addition to the personality traits, the cultural values are also likely to be an important factor in determining people's attitude and behaviors about seeking psychological help. This is because; culture plays a significant role in identifying the issue, deciding on whether to seek help and evaluating the coping options (Cauce et al., 2002). The studies conducted on culture mostly focus on two main domains, namely individualism and collectivism. While a collectivistic culture prioritizes solidarity and social harmony within a group (Markus \& Kitayama, 1991), an individualistic culture attaches importance to independence, autonomy and individual requirements (Kwan, Bond, \& Singelis, 1997). Kim (2007) claims that loyalty to cultural values in collectivist societies may prevent individuals from seeking professional psychological help. According to a meta-analysis study that was conducted based on 13 studies and on regional and national samples, Asian Americans use the psychological help services 30 to $50 \%$ less than European Americans do (Choi \& Miller, 2014). However, there are conflicting views as to whether the Turkish society is a collectivist or individualist one. In the past, Turkish society was generally described as a collectivist society (İmamoğlu, 1987). However, the new generation appears to display some of the personality traits that are associated with the western individualist culture such as self-confidence, competition and independence (Koydemir, Erel, Yumurtac1, \& Şahin, 2010). As a matter of fact, cultural characteristics of people living in cities and rural areas vary. As we move towards cities, individualism features become more dominant. Therefore, it becomes increasingly important to identify whether individualistic and collectivistic cultural characteristics play role in shaping up the psychological attitudes of the individuals within the Turkish context. 
Besides the personality and cultural values of the individuals, types of coping strategies are also likely to determine their psychological help seeking attitudes. In many cultures, individuals seek social support from their families or have recourse to religious practices prior to seeking psychological help (Dejman, Ekblad, Forouzan, Baradaran-Eftekhari, \& Malekafzali, 2008). For example, who prefer avoidance over dealing with their problems (Sheu \& Sedlacek, 2004) and those who feel themselves adequate enough to cope with their own problems have more negative psychological help seeking attitude (Tracey et al., 1984). On the other hand, there are findings about those who opt for seeking social support and making an effort to deal with the problem have a more positive attitude (Türküm, 1999). Such different findings suggest that this matter should be clarified. Addressing different coping strategies altogether and identifying the role that such coping strategies play in seeking psychological help will make a great contribution to the literature.

It is also possible that having negative automatic thoughts has significant role in the attitudes of individuals in seeking psychological help. Those who have sudden and uncontrolled automatic thoughts (Beck, 2005) are known to have negative self-esteem, negative expectations and feelings of helplessness (Abramson, Metalsky, \& Alloy, 1989). Moreover, they suppose that negative experiences always come from themselves, what is experienced will always result in a negative way and that it is not possible to get rid of them (Rose \& Abramson, 1992). As a matter of fact, this nonfunctional reasoning method leads to trying passively with problems (Gabrys, 2011). Therefore, it is possible that individuals who have these feelings and thoughts need psychological help but negative automatic thoughts refrain from seeking psychological help.

Lastly, gender is another important factor on help seeking attitudes. There are a lot of studies reporting that male university students have more negative help seeking attitudes than their female counterparts (Talebi, Matheson, \& Anisman, 2016), and female ones apply more counseling services than males (Morgan, Ness, \& Robinson, 2003). Gender role conflicts and social norms seem an obstacle for seeking psychological help (Yousaf, Popat, \& Hunter, 2015). Especially masculine gender role orientation and men's restrictive affectivity cause men to hesitate to seek help (Özmete \& Yanardağ, 2016). However, there are some studies reporting no significant gender differences in psychological help seeking attitudes (Masuda, Suzumura, Beauchamp, Howells, \& Clay, 2005). Thus, such mixed results of the gender differences in help seeking attitudes can be addressed by new studies in different cultures.

For the purpose of this research, answers were searched to the following questions:

Do personality traits (extroversion, conscientiousness, agreeableness, openness, neuroticism and negative valence) predict significantly psychological help seeking attitudes?

Do collectivistic and individualistic cultural characteristics significantly predict psychological help seeking attitudes?

Do coping strategies (planful problem solving, seeking social support, accepting responsibility, avoidance, keep-to-self, fatalism and supernatural protection) significantly predict psychological help seeking attitudes?

Do negative automatic thoughts significantly predict psychological help seeking attitudes?

Does gender significantly predict psychological help seeking attitudes?

The hypothesis of the present study and the adapted form of Theory of Planned Behavior are presented in Figure 2 as a whole. 


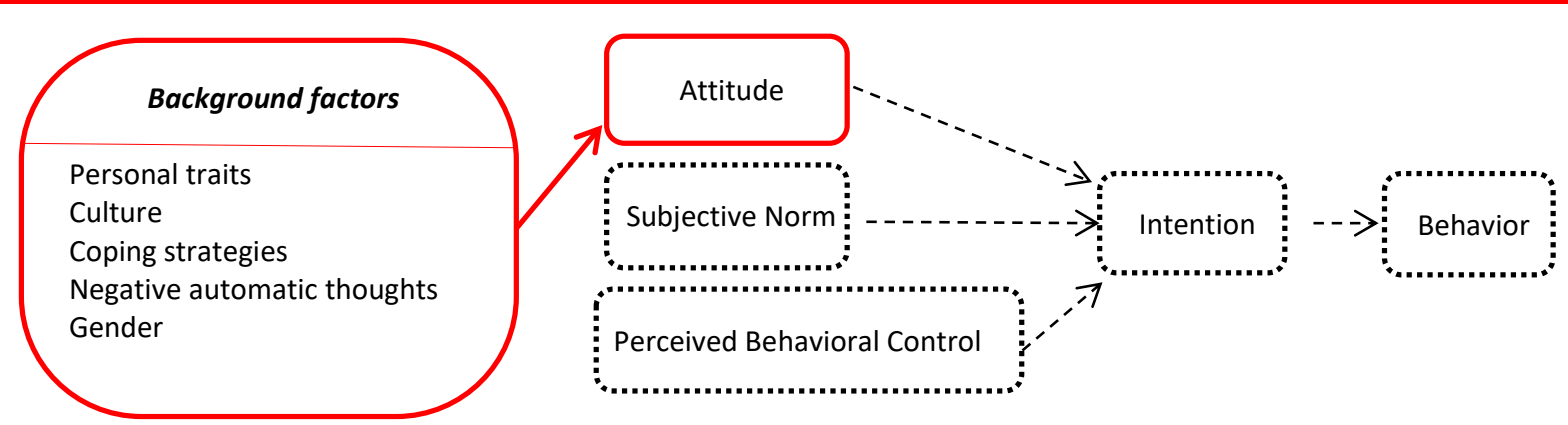

Figure 2. Hypotheses of the study adapted from Theory of Planned Behavior (Ajzen, 1991, p.182)

\section{Importance of the Study}

To mention the importance of research, in college years which include adulthood term, some of the students have difficulties in solving their problems and even fail. Unresolved problems can turn into mental health problems that can damage students' social and academic life. Using adequate and appropriate methods to solve problems plays an improving role for healthy self, in the resolution of adjustment problems, in decreasing the frequency of behavioral problems and depressive symptoms (Steiner, Erickson, Hernandez, \& Pavelski, 2002). The psychological problems of university students have increased 5 times compared to 10 years ago ("İngiltere'de üniversite öğrencilerinin ruh sağlığı,", 2017). The percentage of those who think suicide in university students is $45 \%$ (Eskin, 2012) and $29 \%$ (Eskin, 2017); it is observed that the rate of suicidal attempt varies between 11\% (Eskin, 2012) and 7\% (Eskin, 2017). However, majority of the studies investigated university students do not consider seeking professional psychological help from counseling services (Topkaya \& Meydan, 2013), or are unwilling to apply to there (Wade et al. 2011).

Consequently, it is important to determine factors making students hesitate in seeking professional psychological help. There are no studies presenting the relationship between cultural characteristics on help seeking attitudes of students in Turkey. In addition, it seems that there is a very limited number of studies investigating relationship among personality traits, coping strategies, automatic thoughts and psychological help seeking attitudes. More importantly, it is priceless to investigate the relationship among these variables comprehensively and holistically. Results of the current study are expected to provide new information and extend new horizons. In this way, counselors may plan outreach programs, design services and get educated to be more helpful for counselees.

\section{METHODOLOGY}

This study was designed according to prediction model of correlational design which is a quantitative method. The purpose of a prediction research design is to identify variables that will predict an outcome. In this form of research, the researcher identifies one or more predictor variable and a criterion (outcome) variable (Creswell, 2012). In this study, personality, coping strategy, culture, automatic thought and gender were identified as predictor; and professional psychological help seeking attitude was identified as an outcome (criterion).

\section{Participants}

The study group enrolled in the 2015-2016 fall semester full-time degree program at a university in Turkey. The study consisted of 1284 students (739 female, 493 male) and 2 unidentified students and 254 of them had previously applied a psychological counseling center. The study group has been 
selected out of a total of 21073 students currently studying in 14 different departments of the university through convenience sampling.

In this study, two types of sampling methods were used. Available sampling for participants who did not receive psychological help, and criterion sampling of purposeful sampling strategies was used for those receiving psychological help before.

\section{Measures}

Detailed information about personal information form and Attitudes towards Seeking Professional Psychological Help Scale, Basic Personality Traits Inventory, IND-COL scale, Ways of Coping Questionary and Automatic Thoughts scale were used to collect data in this study and each is presented below.

\section{Personal information form}

In order to determine some demographic characteristics of the participants, a personal information form prepared by the researcher was used. The personal information form includes questions about the participants' gender, class level, the region where they spend most of their lives, the faculty in which they have studied, whether they have received psychological help before and how much they have benefited from it.

\section{Attitudes Towards Seeking Professional Psychological Help Scale - Short form}

Psychological help seeking attitudes was measured using Turkish Form of the Attitudes Towards Seeking Professional Psychological Help Scale - Short Form (ATSPPH-S; Fischer \& Farina, 1995). The adaptation of the scale to the Turkish culture was conducted on adults (Topkaya, 2011). And then the validity and reliability of the study was re-examined with university students (Gürsoy, 2014). The scale consists of 10 items, 5 of which have positive and 5 of which have negative content. Participants were asked to rate each item on a 4-Likert type scale $(1=$ strongly disagree and $4=$ strongly agree $)$. The negatively stated items were then reversed scored since when the points are summed up, a higher score indicates a more positive attitude toward seeking mental health services. Eventually the internal consistency was .84 for original form, .77 for translated form and .77 for current study.

\section{Basic Personality Traits Inventory-BPT}

Basic seven personality traits of Openness, Conscientiousness, Neuroticism, Extraversion, Agreeableness and Negative Values were measured using Basic Personality Traits Inventory-BPT (Gençöz \& Öncül, 2012). The measurement tool was developed in university students. BPT consists of 45 items, with each personality domain scale being made up of different items. Participants are asked to rate each item on a 5-point Likert type scale where 1 is very inaccurate and 5 is very accurate, to the degree to which they believe statements describe them. Scores for the BPT were obtained for each personality dimension, with higher scores representing a stronger presence of that particular personality trait. Internal consistency are between .71 and .89 for original form and estimates of the internal consistency were $.84, .83, .84, .77, .75$ and .64 respectively extraversion, conscientiousness, agreeableness, neuroticism, openness and negative values for current study'.

\section{Individualism-Collectivism (IND-COL) Scale}

Cultural values were measured by using Turkish form of the IND-COL scale (Singelis, Triandis, Bhawuk, \& Gelfand, 1995). The first adaptation of the scale to the Turkish culture was conducted on adults (Wasti \& Erdil, 2007). And then the validity and reliability of the study was re-examined with university students (Dalğar, 2012). IND-COL scale has been shown four-factor structure 
(horizontal/vertical and individualism/collectivism), but it can be used as a two-factor scale (ind/col). IND-COL consists of 37 items rated on a five-point scale ranging from 1 (extremely disagree) to 5 (extremely agree), with higher scores indicating a greater perception of having individualism or collectivism cultural values. IND-COL scale has an acceptable level of internal consistency with a coefficient alpha of ranging from .71 to .73; whereas the current sample's internal consistency was .79 for individualism and .72 for collectivism factor'.

\section{Ways of Coping Questionnaire}

Stress coping styles were measured by using Ways of Coping Questionary (Folkman \& Lazarus, 1980). The adaptation of the scale to the Turkish culture was conducted on university students (Şenol-Durak, Durak, \& Elagöz, 2011). Coping Questionary consists of 31 items rated on a five-point scale ranging from 0 (never) to 3 (always). Coping Questionary has been shown seven-factor structure: Panful Problem Solving, Keep to Self, Seeking Social Support, Escape-Avoidance, Accepting Responsibility, Refuge in Fate, Refuge in Supernatural Forces. Respondent is asked to rate how often they use these strategies when they are in a stressful event and higher scores represent a strong use of that coping styles. Estimates of the internal consistency range from .65 to .80 For current study internal consistency were $.80, .82,66, .43, .75, .81$ and 70 ; respectively planful problem solving, keep to self, seeking social support, escape-avoidance, accepting responsibility, refuge in fate, refuge in supernatural forces.

\section{Automatic Thoughts Questionnaire}

Negative automatic thoughts were measured by using Automatic Thoughts Scale (Hollon \& Kendall, 1980). The adaptation of the scale to the Turkish culture was conducted on university students (Şahin \& Şahin, 1992). The scale consists of 30 items rated on a five-point scale ranging from 1 (never) to 5 (always). It has five -factor structure and can be used with total point. The scale has an acceptable level of internal consistency with a coefficient alpha of ranging from .89 to .91 . Current sample's internal consistency was .96 for this scale and that means it has an acceptable level of internal consistency. High score means individuals have more negative automatic thought.

\section{Data Collection Procedures and Analysis}

Firstly, variables were identified to be employed in the study, and then developers of questionnaires were asked for consent to use related questionnaires. A booklet was created out of the informed consent forms and measurement instruments for the application. With the aim of checking the order effect of the scale, four different booklets - each having the measurement instruments listed in a different order- were distributed to the participants in a random manner. This is because, listing one of the measurement instruments consistently at the end of the list will compromise its reliability (Howitt, 2011) and the inclusion of measurement instruments in studies with different listings will change the study results up to 45\% (Huang \& Cornell, 2015). To control Type I error, participants were selected from both students seeking previously psychological help and ones not seeking. Also, significance level of the regression statistical procedures was identified as $.05 / 4=.01$. Before actual application, pre-test was carried out to check the duration of application and the clarity of the measurement. Later the booklets were carried out 1415 voluntary students at classroom. Voluntary students were given pencils as a gift to fill up the forms earnestly.

Prior to starting analysis, the issue of dealing with the lost data was addressed to make data compatible with the analysis. It is said that there are three ways to deal with the lost data: (1) addition of new observations to preexisting data, (2) removing the observations with lost data out of the data set and (3) assigning approximate values instead of the lost data (Çüm \& Gelbal, 2015). It is suggested that the lost data should be totally randomly distributed to be removed, otherwise removal thus made will be hugely prejudiced and partial (Little \& Rubin, 2002). If the ratio of the lost data is below 1\%, the loss is deemed to be immaterial (Pyle, 1999). In the present study it was found that the lost did not have a normal distribution and its ratio is $0.3 \%$. When the ratio of lost data is minimal, it is recommended that simple 
assignment based methods are used such as assigning series means, near point median assignment, linear valuation etc. (Osborne, 2013; Schafer, 1999). In line with the aforementioned, approximate values have been assigned for the lost data by using the series mean assignment method.

Prior to the analysis of the data, the preliminary conditions of regression were examined. In this respect, care was taken to ensure that the kurtosis-skewness values were between -1.5 and +1.5 (Tabachnick \& Fidell, 2013), and that the Tolerance values were less than .10 and VIF value was more than 10 to eliminate the issue of multiple linear relation between the variables (Field, 2005) and that the relationship between the variables was less than .80 (Garson, 2012). While there are various different views as to the sufficient sample size for a regression analysis, this study employed the most strict view, which stipulates that the ratio of number of participants/predictor variables should be 40/1 (Tabachnick \& Fidell, 2013). In addition to the aforementioned criteria, Mahalanobis distance values were reviewed for normal distribution and it was ensured that the Durbin-Watson value was between 1 and 3 to verify that there was no autocorrelation issue (Akbulut, 2010). The data obtained was analyzed by using the SPSS software package and the significance level of the statistical procedures was identified as .05 for correlation, .01 for regression analysis. In the study, hierarchical regression analysis was chosen because some variables consist of sub-dimensions and it is necessary to include all sub-dimensions of one variable together.

\section{FINDINGS}

Before regression analysis, with the aim of determining significant relationships between variables Pearson Correlation analysis was performed. It was established that dependent variable had a statistically significant relationship with nine independent variables of 16 ones of the study. That is why; the regression analysis should be conducted with the independent variables that had significant relationships with the dependent variable of the study. In addition to the aforementioned variables, the variable of gender was coded as dummy variable $($ male $=1)$ and added to the analyses as a predictor. Hierarchical multiple regression analysis was carried out in four stages according to the order of importance of the variables. Firstly, the personality traits were added to the model, then the cultural traits, the third coping strategies and finally the gender.

Firstly, some of the premises were reviewed to determine the degree of reliability of the analysis results. For the multiple linear relation problem, variance inflation factor (VIF) varied between 1.09 and 1.51, while the tolerance values between .66 and .91. In order to verify the normality condition, the Normal P-P Plot and Scatterplot charts were examined and it was found that the normality condition was met. Lastly, the Durbin-Watson value was reviewed to determine the absence of autocorrelation and no autocorrelation was found between the values (2.04). Once aforementioned premises were met, it was concluded that the results of the regression analysis presented in the tables could be taken into consideration. Results of hierarchical multiple regression analysis for variables predicting university students' psychological help seeking attitudes are presented in the Table 1.

As seen in the Table 1, the Model 1 (containing the dimensions of the personality traits variable) was found to be statistically significant $(\mathrm{p}<.001)$. When the standardized coefficients of the predictor variables $(\beta)$ are taken into consideration, it was found that personality traits of negative valence $(\beta=-$ $.08)$, agreeability $(\beta=.11)$, openness $(\beta=-.17)$ and conscientiousness $(\beta=.07)$ were significant predictors of the university students' attitudes towards seeking psychological help, whereas the neuroticism $(\beta=-$ $.02)$ was not a significant predictor of the latter $(F(5-1281)=14.160,(p<.001)$. When the explanatory strength of the model is taken into consideration, it is seen that it accounts for $5 \%$ of the attitude towards seeking psychological help along with the personality traits dimensions. 
Table 1.

Summary of hierarchical regression analysis for variables predicting help seeking attitudes of university students

\begin{tabular}{|c|c|c|c|c|c|c|c|c|c|c|}
\hline Model & $\begin{array}{l}\text { Dependent } \\
\text { variables }\end{array}$ & B & $\begin{array}{l}\text { Standard } \\
\text { error }\end{array}$ & $\begin{array}{l}\text { Beta } \\
(\beta)\end{array}$ & $\mathrm{t}$ & $\mathrm{p}$ & $\mathrm{R}$ & $\mathrm{R} 2$ & $\Delta \mathrm{R} 2$ & $\mathrm{~F}$ \\
\hline \multirow{6}{*}{1} & Constant & 27.447 & 1.423 & & 19.289 & .001 & \multirow{6}{*}{.23} & \multirow{6}{*}{.05} & \multirow{6}{*}{.05} & \multirow{6}{*}{14.160} \\
\hline & Neuroticism & -.033 & .036 & -.027 & -.928 & .354 & & & & \\
\hline & Negative valence & -.159 & .060 & -.082 & -2.656 & .008 & & & & \\
\hline & Agreeableness & .149 & .040 & .117 & 3.707 & .001 & & & & \\
\hline & Openness & -.217 & .037 & -.176 & -5.878 & .001 & & & & \\
\hline & Conscientiousness & .063 & .026 & .072 & 2.413 & .016 & & & & \\
\hline \multirow{7}{*}{2} & Constant & 25.804 & 1.609 & & 16.042 & .001 & \multirow{7}{*}{.24} & \multirow{7}{*}{.06} & \multirow{7}{*}{.05} & \multirow{7}{*}{12.625} \\
\hline & Neuroticism & -.033 & .036 & -.027 & -.924 & .356 & & & & \\
\hline & Negative valence & -.153 & .060 & -.079 & -2.557 & .011 & & & & \\
\hline & Agreeableness & .120 & .042 & .094 & 2.841 & .005 & & & & \\
\hline & Openness & -.205 & .037 & -.167 & -5.515 & .001 & & & & \\
\hline & Conscientiousness & .053 & .026 & .061 & 2.029 & .043 & & & & \\
\hline & Collectivism & .035 & .016 & .065 & 2.178 & .030 & & & & \\
\hline \multirow{10}{*}{3} & Constant & 26.701 & 1.712 & & 15.599 & .001 & \multirow{10}{*}{.30} & \multirow{10}{*}{.09} & \multirow{10}{*}{.09} & \multirow{10}{*}{14.295} \\
\hline & Neuroticism & -.031 & .036 & -.025 & -.859 & .391 & & & & \\
\hline & Negative valence & -.124 & .059 & -.064 & -2.094 & .036 & & & & \\
\hline & Agreeableness & .091 & .042 & .071 & 2.167 & .030 & & & & \\
\hline & Openness & -.185 & .037 & -.151 & -5.039 & .001 & & & & \\
\hline & Conscientiousness & .055 & .026 & .064 & 2.145 & .032 & & & & \\
\hline & Collectivism & .013 & .017 & .024 & .772 & .440 & & & & \\
\hline & Keep to self & -.210 & .043 & -.142 & -4.834 & .001 & & & & \\
\hline & Seek social supp. & .133 & .054 & .077 & 2.466 & .014 & & & & \\
\hline & Avoidance & .095 & .044 & .060 & 2.141 & .032 & & & & \\
\hline \multirow{11}{*}{4} & Constant & 27.065 & 1.663 & & 16.278 & .001 & \multirow{11}{*}{.38} & \multirow{11}{*}{.14} & \multirow{11}{*}{.14} & \multirow{11}{*}{21.443} \\
\hline & Neuroticism & -.071 & .035 & -.058 & -2.045 & .041 & & & & \\
\hline & Negative valence & .027 & .060 & .014 & .442 & .658 & & & & \\
\hline & Agreeableness & .055 & .041 & .043 & 1.357 & .175 & & & & \\
\hline & Openness & -.083 & .037 & -.068 & -2.222 & .026 & & & & \\
\hline & Conscientiousness & .027 & .025 & .031 & 1.058 & .290 & & & & \\
\hline & Collectivism & .017 & .016 & .032 & 1.076 & .282 & & & & \\
\hline & Keep to self & -.179 & .042 & -.121 & -4.221 & .001 & & & & \\
\hline & Seek social supp. & .132 & .052 & .077 & 2.524 & .012 & & & & \\
\hline & Avoidance & .032 & .044 & .020 & .730 & .465 & & & & \\
\hline & Gender (Male) & -2.778 & .315 & -.263 & -8.831 & .001 & & & & \\
\hline
\end{tabular}

$\mathrm{p} \leq .01$

When the collectivism variable was added to the Model 2, the structure once again retained its statistical significance $(p<.001)$. When the standardized coefficient of the collectivism variable $(\beta=.06)$ was examined it was found to be a statistically significant predictor of the university students' attitudes towards seeking psychological help $(\mathrm{F}(6-1281)=12.625, \mathrm{p}<.001)$. The personality traits and collectivism account for approximately $6 \%$ of the psychological help seeking attitude.

When the three dimensions of the coping strategies were added to the Model 3, the statistical significance of the structure seemed to remain the same $(\mathrm{p}<.001)$. Following the examination of the standardized coefficients of the coping strategies, keep-to-self $(\beta=-.14)$, social support $(\beta=.07)$ and avoidance $(\beta=.06)$ were found to be statistically significant predictors of the university students' attitudes towards seeking psychological help $(\mathrm{F}(6-1281)=14.295, \mathrm{p}<.001)$. However, the collectivism variable that was found to be a significant predictor in the previous model does not appear to be a significant predictor in this particular model $(p>.05)$. When the explanatory strength of the model is 
taken into consideration, it appaers that the dimensions of personality traits, collectivism and coping strategies account for $9 \%$ of the university students' attitudes towards seeking psychological help.

Lastly, the variable of gender was added to the Model 4, as a result of which the model appeared to remain statistically significant $(\mathrm{p}<.001)$. Following the examination of the standardized coefficient of the gender variable $(\beta=-.26)$ it was found to be a statistically significant predictor of the university students' attitudes towards seeking psychological help $(\mathrm{F}(10-1281)=21.443, \mathrm{p}<.001)$. However, the personality traits dimensions of negative valence, agreeability and consciousness and avoidance coping strategies -which were found to be statistically significant predictors in the previous models ceased to be statistically significant predictors $(p>.05)$. On the other hand, the dimension of neuroticism $(\beta=-.05)$ that was found to be an insignificant predictor in the first model was found to be a significant one in this model $(\mathrm{p}<.001)$. When the explanatory strength of the model is taken into consideration, it accounts for $14 \%$ of the university students' attitudes towards seeking psychological help.

\section{DISCUSSION AND CONCLUSION}

The aim of this study is to determine the important factors on university students' psychological help seeking attitudes. In this context, according to the results of the study, personality traits, coping strategies, cultural traits and genders were found to be important variables.

When the findings of the present study are viewed, agreeableness personality trait is found to be an important predictor of the university students' professional psychological help seeking attitudes. This finding seems to be in parallel with the findings of various other studies. It is found that the persons who have previously applied a therapy (Hopwood et al., 2008) and have positive psychological help seeking attitudes (Cardella-Filaski, 2010) demonstrate high degrees of agreeable personality traits. Moreover, it is suggested that persons demonstrating suspicious, aggressive and selfish qualities (indicators of disagreeable personality) reject to receive help (Bridges, Wormley, Leavitt, \& McCord, 2016). It is argued that the individuals with agreeable personality traits are reliable, forgiver, trustworthy (McCrae \& Costa, 2008), well intentioned and trustful (Kakhnovets, 2011). In this respect, it can be argued that the individuals showing agreeable personality traits will not avoid from seeking help from others to solve their own problems since they believe that others can help them whenever they are in need and thus, they have a positive attitude towards seeking psychological help.

Another personality trait that serves as a predictor of the students' attitudes towards seeking psychological help is conscientiousness. Conscientiousness has been found to be a significant predictor in some other studies in the literature. According to a study, the persons who sought help for anorexia nervosa treatment were found to possess a significant degree of conscientiousness (Bridges et al., 2016). In a similar vein, of the individuals who were diagnosed with severe depression, those with high degree of conscientiousness were found to have a more positive attitude towards seeking psychological help (Schomerus et al., 2013). Moreover, it is suggested that the personality trait of conscientiousness is a significant positive predictor of the university students' attitudes towards seeking psychological help even if they have not been previously diagnosed with any psychological disorder (Cardella-Filaski, 2010). It is reported that the individuals with conscientious personality traits show the qualities of being organized, diligent, determined and highly self-conscious (Engler, 2013). In this respect, it can be argued that the conscientious individuals will be aware of the problems they encounter and make a plan to deal with those problems and put up a struggle to operationalize their plan and seek any help to achieve their goal. When the personality traits of the conscientious people and the findings of the present study are taken into account, it can be argued that such people view psychological help services as a source of help and thus they have a positive attitude towards seeking help from counseling services. 
It is found that the individuals with high degree of openness personality trait have a significant negative attitude towards seeking help. This finding differs from the findings of previous studies. A study conducted on university students shows that those with a higher degree of openness have a more positive attitude towards seeking psychological help (Atik \& Yalçın, 2011; Hinrichs, 2012). Another study presenting similar results explains this situation through the fact that the individuals that are open to new experiences are aware of the fact that they need help, and that they are more resistant against social stigma, and that they have a higher sense of interpersonal openness and a higher degree of trust in the therapy (Drancoli, 2007). People that are open to new experiences are described as curious, interested and enterprising (Cervone \& Pervin, 2014). In this respect, the individuals with a high degree of openness are expected to have positive attitudes towards seeking psychological help. However, the fact that the conclusion of this study differs from others leads one to think that people with a higher degree of openness no longer view psychological help services as an innovation or that they do not think help services will be useful for them. However, more in-depth studies -such as interviewing with people with a higher degree of openness- can be conducted to obtain more detailed results and to perform indepth analysis.

It has been found that individuals with higher degree negative valence have more negative attitudes about psychological help seeking. Unfortunately, there are no studies related this personality trait. Nonetheless, there are studies conducted based on the factors associated with the negative valence personality trait. Individuals with negative valence personality traits have quite negative self-worth, self-esteem and they roll with the punch and make no effort to alter their situation and avoid seeking social support (Gençöz \& Öncül, 2012). In another study, it is suggested that the individuals with low self-worth and self-esteem have a more negative attitude about psychological help seeking (Dorazio, 2013). In this respect, it can be argued that the individuals with negative valence may require support on account of their low self-esteem. However, they can avoid taking initiative to alter their situation. That is because; they have the anxiety of social stigma, in particular, due to their lack of self-esteem (Ho et al., 2015). In addition, due to the aforementioned reasons, one may conclude that they would avoid seeking psychological help and thus have negative psychological help seeking attitudes.

Lastly, the personality trait of neuroticism does not appear to be a significant predictor of the participants' attitudes towards seeking psychological help. This finding is supported by various studies in the literature. (Atik \& Yalçın, 2011; Sauder, 2014). For example, neuroticism levels do not differ between those who have previously received psychological help and those who have not (Bridges et al., 2016) and that it is not an important factor in determining whether or not to apply to help services (Have, Oldehinkel, Vollebergh, \& Ormel, 2005). The personality traits of neurotic persons are mostly reported as anxious, insecure, sensitive to stress related disorders and incapable of coping with such disorders (Miserandino, 2014). In this respect, it can be suggested that neurotic individuals may need psychological help. As such, one would expect neuroticism to be a significant predictor of the attitude towards seeking help. However, when gender was added to model, neuroticism became a significant predictor of help seeking attitudes. This means the relationship between neuroticism and help seeking attitudes changes in terms of participants' gender. More detailed results regarding this matter may be presented through the studies to be conducted using different analyses or methods and qualitative findings.

In this study, students' -who adopt collectivistic cultural characteristic-, psychological help seeking attitudes are more positive. While this result shows similarities to some studies, it differs from most of the studies in the literature. In a study conducted with the overseas university students from various cultural backgrounds, it has been found that the students related to Asian culture -which is deemed to be a largely collectivist culture- have a more positive attitude towards seeking psychological help (Yakunina \& Weigold, 2011). The characteristics of a collectivist culture are listed as a desire to be identified with the opinion, requirements and purposes of their group; adjusting one's behaviors in line with the social norms and tasks; willing to espouse common beliefs and values and be in collaboration with the group members (Triandis, 1990). Values in a collectivist culture mostly consist of security, good social relations and group integrity (Eshun \& Gurung, 2009). Moreover, collectivist individuals 
also value the attitudes that reflect socialization, loyalty and family integrity (Hogg \& Vaughan, 2014). As a means of social support, individuals in a collectivist culture may firstly start seeking help from their family and relatives and then from their friends and gradually from people outside their social network. In this respect, counseling services can be considered as a means of social support for them. As a conclusion, it can be argued that such people may regard counseling services as social support and have a positive attitude towards seeking psychological help.

On the other hand, there is a good number of studies pointing out that persons in living in a collectivist society have a negative attitude towards seeking psychological help (Choi, 2012; Choi \& Miller, 2014; Hamid \& Furnham, 2013; Mojaverian et al., 2013; Mori, Panova, \& Keo, 2007; Nater, 2013). However, such studies have mostly taken individualistic and collectivistic cultures as two incompatible dimensions. In this respect they have compared the two cultural structures. However, recently it has been suggested that two cultures should be considered as two different structures, rather than incompatible dimensions, and be measured as such (Kim, 1994). Moreover, the early studies mostly concluded that the fact that the individuals in a collectivist culture had a negative attitude about psychological help seeking was down to their distrust in the effectiveness of psychotherapy (Mori et al., 2007) and their anxiety of social stigma (Miville \& Constantine, 2006). Today, on the strength of the evidence that the applications to counseling services have relatively increased, it can be argued that people may have somewhat managed to overcome their anxiety of stigma and have a more positive attitude towards seeking help.

The stress coping strategies of keep to self, seeking social support and avoidance have been found to be significant predictors of the students' attitudes towards seeking psychological help. It has been established that the students using coping strategy of keep-to-self have a more negative attitude about psychological help seeking. This result appears to share similarity with the findings of other studies. A study conducted with people from various cultural backgrounds has found that the participants have avoided treatment due to their anxiety of losing face and falling into disgrace and, instead, tried to conceal their problems from the public (Porrett, 2010). Another study conducted with the members of the clergy has found that the participants were aware of the fact that they needed help but chose to conceal their problems for the sake of protecting their reputation (Pietkiewicz \& Bachryj, 2016). Regardless of whether or not they are aware of their problems, those who opt for the coping strategy of keep-to-self do not wish others to get wind of their situation and know how much difficulty they are in and thus shy away from talking about their issues to others (Şenol-Durak et al., 2011). Consequently, it can be argued that they have a negative attitude towards seeking help because they focus more on the assumed negative sides of the consultation services and they think others will notice about their problems or they will lose face in public because of that.

It has been established that students who opt for the coping strategy of seeking social support have a more positive attitude towards seeking psychological help. There are a lot of studies showing similarities to this result. For example, it was stated that participants who use seeking social support coping strategy had a more positive attitude about psychological help seeking (Avent, Cashwell, \& Brown-Jeffy, 2015; Roldan-Bau, 2013). Similarly, another study conducted with the university students from various different ethnic backgrounds has found that the participants who used the coping strategies of seeking emotional and social support had a more positive attitude towards seeking psychological help (Niegocki, 2010). The coping strategy of seeking social support can be described as an individual's request of help from their family, relatives, friends or any other stranger when the individual has a problem. In this respect, psychological help services may be considered as a means of social support. As a conclusion, those who request talking about their emotions or problems to others are expected to have positive psychological help seeking attitudes as a social support.

It has been established that the participants who use the coping strategy of avoidance have a more positive attitude about psychological help seeking. Similarly, a study conducted exclusively with males has found that the participants opting for the coping strategy of avoidance have a more positive attitude (Spry \& Walker, no date). Those who use the coping strategy of avoidance choose to stay away from 
and ignore the situation and engage in different activities such as eating or drinking rather than tackling it (Nater, 2013). At first glance, these findings can be considered as contradictory results, but they are not. On the one hand, applying to counseling services may be viewed as a purposeful and planful way of getting rid of one's problems; on the other hand, it can also be interpreted as a way of avoiding facing up to problems. This is because, individuals may be avoiding facing up to their problems by talking about other issues or leaving the responsibility of solving issues to others in counseling services. Therefore, it is somehow expected for them to have a positive psychological help seeking attitudes with the aim of expectancy for services to provide them the means to avoid their problems.

Lastly, gender has been found to be a significant predictor of the students' attitudes towards seeking psychological help. In other words, male students have been found to possess a more negative psychological help seeking attitude than female students. This result is in parallel with almost all of the research findings available. It is suggested that males' negative attitudes are about psychological help seeking owing to their gender roles (Özdemir, 2012; Yousaf et al., 2015) and the anxiety of both social and self-stigma (Talebi et al., 2016). Social setting and teachings may have a bearing on the development of the individual's attitudes and behaviors. In this respect, the gender roles ascribed to males and females by the society may influence their attitudes towards seeking psychological help. According to the common gender roles, females are mostly regarded as inclined to cooperation and in need of support. In contrast, males are expected to be strong, capable of dealing with their own problems and show no sign of weakness (Özmete \& Yanardağ, 2016). According to a study, Turkey is ranked 48th among 60 countries in terms of gender equality (Esmer, 2012). This casts evidences on that the social gender roles are very dominant in the Turkish society. As a conclusion, it can be argued that male students avoid going to psychological counseling services and have a negative attitude because they wish to avoid looking weak by expressing their emotions and seeking help and live up to the roles ascribed to them by the society and successfully maintain their roles.

In the last model, neurotic and open personality, the stress coping strategies of self-concealment and social support, and gender remain as important determinants of the students' about seeking psychological help attitudes.

It appears that the variables in existing studies integrated in TPB theory are part of this theory. It was tried to determine the variables behind the psychological help seeking attitudes in the basic structure of TPB theory, and it was proved. Current research findings show personality, cultural values, stress coping strategies and gender are the determinants of psychological help seeking attitudes.

Some important findings that are not intended for this study are noteworthy. When coping strategies were added to the model, the predictive level of collectivism became insignificant. It suggests that coping strategies can play mediating roles between collectivist cultural characteristics and attitudes towards seeking help. In addition, it was found that the predictive levels of some personality traits and coping strategies were insignificant with the addition of gender variable to the model. This finding indicates that gender has a moderator role in the relationship of personality traits and coping strategies with help seeking attitudes. In other words, the relationship between these variables varies according to gender. In order to make a more reliable interpretation on this issue, firstly, analyses should be performed with the structural equation model which contains more strict rules. Then the mediation and moderation effect of the aforementioned variables can be discussed in the light of the literature.

To summarize, in the framework of personality traits, it can be said that while university students who had higher agreeableness and conscientiousness personality traits had a more positive help seeking attitudes, students who had openness and negative valence personality traits have more negative attitudes. Also, it was found that students with high collectivistic culture have more positive psychological help seeking attitude. In the context of stress coping methods, students who use social support and avoidance coping methods have more positive attitudes, whereas those who use keep-toself methods have more negative holdings. Lastly, it was found women's help seeking attitudes are more positive than men's. 
The current study has several limitations. Since many variables are considered in this study at the same time, predictions of some may be suppressed. In subsequent studies these variables can be examined separately. Since participants of the study consist of both university students who did and did not seek help, it may limit the generalizability of the result to other samples such as child, adults or others in different profession areas.

Despite these limitations, the current study has several implications for practices. Given the present findings, there is a need to train counselors' sensitiveness about to train counselors sensitive about the factors that influence students' help seeking attitudes. A clearer understanding of the association among personality, stress coping strategy, collectivism, automatic thoughts, gender and help-seeking attitudes may enable mental health service providers to develop and refine interventions programs specifically. In addition, a variety of activities, such as psycho-education group activities, can be undertaken to change students' negative psychological help seeking attitudes. If outreach programs provide basic information of professional psychological services, they may be more effective. In addition, helping students have effective stress coping strategies may be vitally important for students with healthier mental/psychology.

\section{Acknowledgement}

This study was produced from the doctoral dissertation of İsmail Yelpaze, carried out under the academic counseling of Aydoğan Aykut Ceyhan.

\section{REFERENCES}

Abramson, L. Y., Metalsky, G. I., \& Alloy, L. B. (1989). Hopelessness depression: A theory-based subtype of depression. Psychological Review, 96(2), 358-372.

Ajzen, I. (1985). From intentions to actions: A theory of planned behavior In J. Kuhl, J. Beckman (Eds.), Action control: From cognition to behavior. Heidelberg: Springer.

Ajzen, I. (1991). The theory of planned behavior. Organizational behavior and human decision processes, 50(2), $179-211$.

Akbulut, Y. (2010). Sosyal bilimlerde SPSS uygulamaları [SPSS applications in social sciences]. İstanbul: İdeal Kültür Yayıncilık

Atik, G., \& Yalçın, İ. (2011). Help-seeking attitudes of university students: The role of personality traits and demographic factors. South African Journal of Psychology, 41(3), 328-338.

Avent, J. R., Cashwell, C. S., \& Brown-Jeffy, S. (2015). African American pastors on mental health, coping, and help seeking. Counseling and Values, 60(1), 32-47.

Barenbaum, N. B., \& Winter, D. G. (1999). History of modern personality theory and research. In O. P. John, R. W. Robins, \& L. A. Pervin (Eds.), Handbook of personality: Theory and research (pp. 3-28). USA: Guilford Press.

Beck, A. T. (2005). The current state of cognitive therapy: A 40-year retrospective. Arch Gen Psychatry, 62, 953957.

Bridges, A. N., Wormley, K. A., Leavitt, I. W., \& McCord, D. M. (2016). Personality differences in treatmentseeking and non-treatment-seeking individuals with self-reported anorexia. International journal of adolescent medicine and health, 29(5). DOI: 10.1515/ijamh-2015-0116

Cardella-Filaski, K. (2010). Predicting the likelihood of help-seeking in adolescents: The role of personality variables, social support, gender, and type of problem (Unpublished doctoral dissertation). St. John's University, New York.

Cauce, A. M., Domenech-Rodríguez, M., Paradise, M., Cochran, B. N., Shea, J. M., Srebnik, D., \& Baydar, N. (2002). Cultural and contextual influences in mental health help seeking: a focus on ethnic minority youth. Journal of Consulting and Clinical Psychology, 70(1), 44.

Cepeda-Benito. A., \& Short, P. (1998). Self-concealment, avoidance of psychological services, and perceived likelihood of seeking professional help. Journal of Counseling Psychology, 45, 58-64. 
Cervone, D., \& Pervin, L. A. (2014). Personality psychology. Singapore: John Wiley and Sons Pte. Ltd. Publications

Ceyhan, E. (2009, July). Psychological characteristics of Turkish university students applying the counseling center. Paper presented at International Conference on Education and New Learning Technology (EDULEARN09), Barcelona, Spain.

Choi, N. Y. (2012). Effects of culture and stigma on attitudes toward seeking psychological help and willingness to see a counselor in Asian American college students (Unpublished doctoral dissertation). University of Maryland, College Park

Choi, N.Y., \& Miller, M. J. (2014). AAPI college students' willingness to seek counseling: The role of culture, stigma, and attitudes. Journal of Counseling Psychology, 61(3), 340-351. DOI: 10.1037/cou0000027

Cramer, K. M. (1999). Psychological antecedents to help-seeking behavior: A reanalysis using path modeling structures. Journal of Counseling Psychology, 46(3), 381-387. DOI: 10.1037/0022-0167.46.3.381.

Creswell, J. W. (2012). Educational research: Planning, conducting, and evaluating quantitative and qualitative research. Boston: Pearson Publication

Çüm, S., \& Gelbal, S. (2015). The effects of different methods used for value imputation instead of missing values on model data fit statistics. Mehmet Akif Ersoy University Journal of Education Faculty, 1(35), 87-111.

Dalğar, İ. (2012). Relational models theory and their associations with cultural orientations and personal value priorities in the Turkish cultural context (Unpublished master's thesis). Middle East Technical University, Ankara.

Dejman, M., Ekblad, S., Forouzan, A. S., Baradaran-Eftekhari, M., \& Malekafzali, H. (2008). Explanatory model of help-seeking and coping mechanisms among depressed women in three ethnic groups of Fars, Kurdish, and Turkish in Iran. Archives of Iranian Medicine, 11(4), 397-406.

Dennis, J., Phinney, J., \& Chuateco, I. (2005). The role of motivation, parental support, and peer support in the academic success of ethnic minority first-generation college students. Journal of College Student Development, 46(3), 223-236. DOI: 10.1353 /csd.2005.0023.

Dorazio, C. (2013). The impact of ethnic identity on attitudes towards counseling for Italian-Americans (Unpublished doctoral dissertation). Columbia University, NY.

Drancoli, V. (2007). Personality, ethnicity, and help seeking attitudes in college students (Unpublished doctoral dissertation). California State University, Los Angeles.

Engler, B. (2013). Personality theories. Wadsworth, Ohio: Cengage Learning.

Erkan, S., Cihangir-Çankaya, Z., Terzi, Ş., \& Özbay, Y. (2011). An assessment of university counseling and guidance centers. Mehmet Akif Ersoy University Journal of Education Faculty, 11(22), 174-198.

Eshun, S., \& Gurung, R. A. (2009). Culture and mental health: Sociocultural influences, theory, and practice. UK: John Wiley \& Sons.

Eskin, M. (2012). The role of childhood sexual abuse, childhood gender nonconformity, self-esteem and parental attachment in predicting suicide ideation and attempts in Turkish young adults. Suicidology Online, 3, 114123.

Eskin, M. (2017). Suicidal idea, attempt and attitudes among young people. Turkish Journal of Psychology, 32(80), 93-115.

Esmer, Y. (2012). Türkiye değerler atlası 2012 [Turkey values atlas 2012]. İstanbul: Bahçeşehir Üniversitesi Yayınlar1.

Field, A. (2005). Discovering statistics using SPSS. London: Sage Publication

Fischer, E. H., \& Farina, A. (1995). Attitudes toward seeking professional psychological help: A shortened form and considerations for research. Journal of College Student Development, 36, 368-373.

Folkman, S., \& Lazarus, R. S. (1980). An analysis of coping in a middle-aged community sample. Journal of Health and Social Behavior, 21, 219-239.

Gabrys, R. (2011). The role of negative automatic thoughts on stress-related processes and symptoms of depression (Unpublished master's thesis). Carleton University, Ottawa.

Garson, G. D. (2012). Testing statistical assumptions. Asheboro: G. David Garson and Statistical Associates Publishing. Retrieved from https://faculty.chass.ncsu.edu/garson/PA765/statnote.htm

Gençöz, T., \& Öncül, Ö. (2012). Examination of personality characteristics in a Turkish sample: Development of basic personality traits inventory. The Journal of General Psychology, 139(3), 194-216.

Goodwin, M. E. (2008). Gender role conflict, depression, and personality's effect on help seeking behaviors, attitudes, and academic performance (Unpublished doctoral dissertations). Iowa State University, Iowa.

Güneri, O., Aydın, G., \& Skovholt, T. (2003). Counseling needs of students and evaluation of counseling services at a large urban university in Turkey. International Journal for the Advancement of Counselling, 25, 5363.

Gürsoy, O. (2014). The role of social stigma, personal stigma, distress disclosure, self-esteem and gender predicted the attitudes toward psychological help-seeking of the university students according to prior 
professional psychological counseling experience (Unpublished master's thesis). Mersin University, Mersin.

Hamid, A., \& Furnham, A. (2013). Factors affecting attitude towards seeking professional help for mental illness: An UK Arab perspective. Mental Health, Religion \& Culture, 16(7), 741-758. DOI: 10.1080/13674676.2012.718753

Have M. T., Oldehinkel, A., Vollebergh, W., \& Ormel, J. (2005). Does neuroticism explain variations in care service use for mental health problems in the general population? Social Psychiatry Psychiatr Epidemiology, 40, 425-431.

Health topics: Country work. (2019). World Health Organization. Retrieved from http://www.euro.who.int/en/health-topics/noncommunicable-diseases/mental-health/country-work

Hinrichs, J. C. (2012). The relationship between personality and treatment preference (Unpublished doctoral dissertation). Saint Louis University, Missouri.

Ho, A. H., Potash, J. S., Fong, T. C., Ho, V. F., Chen, E. Y., Lau, R. H., ... \& Ho, R. T. (2015). Psychometric properties of a Chinese version of the Stigma Scale: examining the complex experience of stigma and its relationship with self-esteem and depression among people living with mental illness in Hong Kong. Comprehensive psychiatry, 56, 198-205. DOI: 10.1016/j.comppsych.2014.09.016

Hogg, M. A., \& Vaughan, G. M. (2014). Sosyal psikoloji [Social psychology] (Translater: İ. Yıldız \& A. Gelmez). Ankara: Ütopya Publication.

Hollon, S. D., \& Kendall, P. C. (1980). Cognitive self-statements in depression: Development of an automatic thoughts questionnaire. Cognitive Therapy and Research, 4(4), 383-395.

Hopwood, C. J., Quigley, B. D., Grilo, C. M., Sanislow, C. A., McGlashan, T. H., Yen, S., ... \& Markowitz, J. C. (2008). Personality traits and mental health treatment utilization. Personality and Mental Hhealth, 2(4), 207-217. DOI: $10.1002 / \mathrm{pmh} .51$.

Howitt, R. (2011). Theoretical foundations. In F. Vanclay \& A. M. Esteves (Eds.), New directions in social impact assessment: Conceptual and methodological advances (pp. 78-95). UK: Edward Elgar Publishing

Huang, F. L., \& Cornell, D. G. (2015). Question order affects the measurement of bullying victimization among middle school students. Educational and Psychological Measurement, 76(5), 724-740. DOI: $10.1177 / 0013164415622664$.

İmamoğlu, E. O. (1987). An interdependence model of human development. In Ç. Kagitcibasi (Ed.), Growth and progress in cross-cultural psychology (pp. 138-145). Lisle: Swets and Zeitlinger.

Infographic - Depression in Turkey. (2017). World Health Organization. Retrieved from http://www.euro.who.int/en/countries/turkey/data-and-statistics/infographic-depression-in-turkey-2017

İngiltere'de üniversite öğrencilerinin ruh sağlı̆̆ı [Mental health of university students in the UK]. (2017, November). BBC News. Retrieved from https://www.bbc.com/turkce/haberler-41157819.

Kakhnovets, R. (2011). Relationships among personality, expectations about counseling, and help-seeking attitudes. Journal of Counseling \& Development, 89, 11-19. https://doi.org/10.1002/j.15566678.2011.tb00056.x

Kelly. A. E., \& Achter, J. A. (1995). Self-concealment and attitudes toward counseling in university students. Journal of Counseling Psychology, 42, 40-46.

Keskin, A., Ünlüoğlu, I., Bilge, U., \& Yenilmez, Ç. (2013). The prevalence of psychiatric disorders distribution of subjects gender and its relationship with psychiatric help-seeking. Archives of Noro-Psikyatri, 50(4), 344-351. DOI: 10.4274/npa.y6522

Kessler, R. C., Berglund, P., Demler, O., Jin, R., Merikangas, K. R., \& Walters, E. E. (2005). Lifetime prevalence and age-of-onset distributions of DSM-IV disorders in the National Comorbidity Survey Replication. Archives of General Psychiatry, 62(6), 593-602.

Kim, B. S. K. (2007). Adherence to Asian and European American cultural values and attitudes toward seeking Professional psychological help among Asian American college students. Journal of Counseling Psychology, 54, 474-480.

Kim, U. (1994). Individualism and collectivism: Conceptual clarification and elaboration. In U. Kim, H. C. Triandis, Ç. Kağıtçıbaşı, S. C. Choi \& G. Yoon (Eds.), Individualism and collectivism: Theory, method and application (pp. 19- 40). Thousand Oaks, CA: Sage.

Koydemir, S., Erel, Ö., Yumurtac1, D., \& Şahin, G. N. (2010). Psychological help-seeking attitudes and barriers to help-seeking in young people in Turkey. International Journal for the Advancement of Counselling, 32, 274-289. DOI: $10.1007 / \mathrm{s} 10447-010-9106-0$

Koydemir-Özden, S., Diker-Coşkun, Y., Yumurtac1, D., Erel, Ö., \& Şahin, G. (2009, September). Counseling needs of university students. Paper presented at 10th National Psychological Counseling and Guidance Convention, Adana.

Kwan, V. S. Y., Bond, M. H., \& Singelis, T. M. (1997). Pancultural explanations for life satisfaction: adding relationship harmony to self-esteem. Journal of Personality and Social Psychology, 73, 1038-1051.

Little, R. J. A., \& Rubin, D. B. (2002). Statistical analysis with missing data. Hoboken, NJ: John Wiley \& Sons. 
Markus, H. R., \& Kitayama, S. (1991). Culture and the self: Implications for cognition, emotion, and motivation. Psychological Review, 98(2), 224.

Masuda, A., Suzumura, K., Beauchamp, K. L., Howells, N. Y., \& Clay, C. (2005). United States and Japanese college students' attitudes toward seeking professional psychological help. International Journal of Psychology, 40(5), 303-313.

McCrae, R. R., \& Costa Jr, P. T. (2008). The five-factor theory of personality. In. O. P. John, R. W. Robins, \& L. A. Pervin (Eds.), Handbook of personality: Theory and research (pp. 159-181). New York: Guilford.

Miserandino, M. (2014). Personality psychology; Foundations and findings. USA: Pearson Higher Education

Miville, M. L., \& Constantine, M. G. (2006). Socio-cultural predictors of psychological help seeking attitudes and behavior among Mexican American college students. Cultural Diversity and Ethnic Minority Psychology, $12,420-432$.

Mojaverian, T., Hashimoto, T., \& Kim, H. S. (2013). Cultural differences in professional help seeking: A comparison of Japan and the U.S. Frontiers in Psychology 3, (article no: 615). DOI: 10.3389/fpsyg.2012.00615

Morgan, T., Ness, D., \& Robinson, M. (2003). Students' help-seeking behaviours by gender, racial background, and student status. Canadian Journal of Counselling, 37, 151-166.

Mori, L., Panova, A., \& Keo, Z. S. (2007). Perceptions of mental illness and psychotherapy in a sample of Asian, Hispanic, and White American college students. Journal of Psychiatry, Psychology, and Mental Health, $1(2), 1-13$.

Nater, U. M. (2013). Escape-avoidance coping. In M. Gellman, \& J. Turner (Eds.), Encyclopedia of behavioral medicine (pp. 708-709). New York, NY: Springer.

Niegocki, K. L. (2010). Coping behaviors, self-efficacy and attitudes toward seeking professional psychological help (Unpublished doctoral dissertation). Ball State University, Muncie.

Osborne, J. W. (2013). Best practices in data cleaning. California: Sage Publication, Inc.

Özdemir, S. (2012). Relations between psychological help seeking attitudes and personality, self-concealment, gender roles (Unpublished master's thesis). Hacettepe University, Ankara.

Özgen, H. (2016). The analysis of the relation between school burnout and the need for psychological help of university students (Unpublished master's thesis). Atatürk University, Erzurum.

Özmete, E., \& Yanardağ, M. Z. (2016). The male perspective on gender roles: The value of being a male or a female. Turkish Journal of Social Research, 1, 91-107.

Perrine, R, M., \& Lisle, J. (1995) Effects of a syllabus offer of help, student age, and class size on college students' willingness to seek support from faculty. Journal of Experimental Education, 64, 41-53.

Pietkiewicz, I. J., \& Bachryj, D. (2016). Help-seeking attitudes and coping strategies among Roman Catholic Secular Clergy. Psychology of Religion and Spirituality, 8(1), 13-24. DOI: 10.1037/re10000019.

Porrett, T. (2010). Coping and help seeking behavior in women with pelvic floor dysfunction-the emic perspective (Unpublished doctoral dissertation). City University of London, London.

Pyle, D. (1999). Data preparation for data mining. San Francisco, CA: Morgan Kaufmann Publishers, Inc.

Rahat, E., \& İlhan, T. (2016). Coping styles, social support, relational self-construal, and resilience in predicting students' adjustment to university life. Educational Sciences: Theory \& Practice, 16(1), 187-208. DOI: 10.12738/estp.2016.1.0058

Roldan-Bau, A. E. (2013). Seeking help for psychological distress: The role of acculturation, family relationships, coping, and stigma among Latin Americans in Canada (Unpublished doctoral dissertations, Paper 4854). University of Windsor, Canada.

Rose, D., \& Abramson, L. (1992). Developmental predictors of depressive cognitive style: Research and theory. In D. Cicchetti \& S. Toth (Eds.), Developmental perspectives on depression (pp. 323-349). Rochester, NY: University of Rochester Press.

Şahin, N. H., \& Şahin, N. (1992). Reliability and validity of the Turkish version of the automatic thought's questionnaire. Journal of Clinical Psychology, 48(3), 334-340.

Şahin-Akaydın, F. (2002). Examining the relationship between university students' problem areas, problematic levels, problem solving skills and help seeking behavior (Unpublished master's thesis). Karadeniz Technical University, Trabzon.

Sareen, J., Jagdeo, A., Cox, B. J., Clara, I., ten Have, M., Belik, S. L., ... \& Stein, M. B. (2007). Perceived barriers to mental health service utilization in the United States, Ontario, and the Netherlands. Psychiatric Services, 58(3), 357-364.

Sauder, J. E. (2014). Personality dimensions and attitudes towards counseling (Undergraduate thesis). University of Florida, Florida.

Schafer, J. L. (1999). Multiple imputation: A primer. Statistical Methods on Medical Resarch, 8(1), 3-15.

Schomerus, G., Appel, K., Meffert, P. J. Luppa, M., Andersen, R. M., Grabe, H. J., \& Baumeister, S. E. (2013). Personality-related factors as predictors of help-seeking for depression: A population-based study applying 
the Behavioral Model of Health Services Use. Soc Psychiatry Psychiatr Epidemiol, 48, 1809-1817. DOI: 10.1007/s00127-012-0643-1.

Şenol-Durak, E., Durak, M., \& Elagöz, F. Ö. (2011). Testing the psychometric properties of the Ways of Coping Questionnaire (WCQ) in Turkish university students and community samples. Clinical psychology \& psychotherapy, 18(2), 172-185. DOI: 10.1002/cpp.677

Sheu, H. B., \& Sedlacek, W. E. (2004). An exploratory study of help-seeking attitudes and coping strategies among college students by race and gender. Measurement and Evaluation in Counseling and Development, 37(3), 130.

Singelis, T. M., Triandis, H. C., Bhawuk, D. P., \& Gelfand, M. J. (1995). Horizontal and vertical dimensions of individualism and collectivism: A theoretical and measurement refinement. Cross-Cultural Research, 29(3), 240-275.

Spry, E., \& Walker, G. (no date). The relationship between conformity to masculine norms, coping strategies and male help-seeking behavior: achieving better health outcomes for men. Unpublished manuscript, Monash Univserity, Melbourne. Retrieved from https://ahsri.uow.edu.au/content/groups/public/@web/@chsd/documents/doc/uow132868.pdf

Steiner, H., Erickson, S. J., Hernandez, N. L., \& Pavelski, R. (2002). Coping styles as correlates of health in high school students. Journal of Adolescent Health, 30(5), 326-335.

Tabachnick, B. G., \& Fidell, L. S. (2013). Using multivariate statistics. Boston: Pearson

Talebi, M., Matheson, K., \& Anisman, H. (2016). The stigma of seeking help for mental health issues: mediating roles of support and coping and the moderating role of symptom profile. Journal of Applied Social Psychology, 46(8), 470-482. DOI: 10.1111/jasp.12376.

Topkaya, N. (2011). Structural equation analysis of willingness to seek psychological help by the roles of social stigma, treatment fears, anticipated benefits, risks, and attitudes toward therapy (Unpublished doctoral dissertation). Ege University, İzmir.

Topkaya, N., \& Meydan, B. (2013). University students' problem areas, sources of help, and intentions to seek psychological help. Trakya University Journal of Education, 3(1), 25-37.

Tracey, T., Sherry, P., Bauer, G., Robins, T., Todaro, L., \& Briggs, S. (1984). Help seeking as a function of student characteristics and program description: A logit-loglinear analysis. Journal of Counseling Psychology, 31, $54-62$.

Triandis, H. C. (1990). Cross-cultural studies of individualism and collectivism. In J. Berman (Ed.), Cross-cultural perspectives: Nebraska Symposium on Motivation (pp. 41-133). Lincoln: University of Nebraska Press.

Türküm, A. S. (1999, September). Relationship between stress coping style, optimism, cognitive distortions, and attitudes towards seeking psychological help: A research on university students. Paper presented at V. National Psychological and Counseling Congress, Ankara.

Ültanır, E. (1998). Validity and reliability study of problem Q sort developed for university student. Turkish Psychological Counseling and Guidance Journal, 2(10), 23-32.

Vogel, D. L., Wester, S. R., Wei, M., \& Boysen, G. A. (2005). The role of outcome expectations and attitudes on decisions to seek professional help. Journal of Counseling Psychology, 52, 459-470.

Wade, N. G., Post, B. C., Cornish, M. A., Vogel, D. L., \& Tucker, J. R. (2011). Predictors of the change in selfstigma following a single session of group counseling. Journal of Counseling Psychology, 58, 170-182.

Wasti, S. A., \& Eser Erdil, S. (2007). Measurement of individualism and collectivism: Validation of self-construal scale and INDCOL in Turkish. Journal of Management Research, 7, 39-66.

World Health Organization. (2008). Global Burden of Disease: 2004 Update. Geneva: World Health Organization Press. $\quad$ Retrieved

from https://www.who.int/healthinfo/global_burden_disease/GBD_report_2004update_full.pdf?ua=1

Yakunina, E. S., \& Weigold, I. K. (2011). Asian international students' intentions to seek counseling: Integrating cognitive and cultural predictors. Asian American Journal of Psychology, 2(3), 219-224. DOI: $10.1037 / \mathrm{a} 0024821$

Yousaf, O., Popat, A., \& Hunter, M. S. (2015). An investigation of masculinity attitudes, gender, and attitudes toward psychological help-seeking. Psychology of Men \& Masculinity, 16(2), 234-237. DOI: $10.1037 / \mathrm{a} 0036241$ 


\section{TÜRKÇE GENIŞLETILMIŞ ÖZET}

İnsanların günlük yaşamlarında sorunlar yaşaması kaçınılmaz bir durumdur. Evde veya işyerinde karşılaşılan bu sorunlar içerisinde zorbalık/şiddet, bezdiri (mobing), istismar gibi psikolojik sorunlar önemli bir yer tutmaktadır. Dünya sağlık örgütü (WHO)'nün araştırmasına göre; 121 milyon kişinin depresyondan, 24 milyon kişinin şizofreniden, 70 milyon kişinin aşırı alkol kullanımından ve 5 milyon kişinin de zararlı madde kullanımından dolayı sorunlar yaşadıkları rapor edilmektedir. Üniversite öğrencilerinin birçok sorunu yaygın biçimde yaşaması, üniversitelerde psikolojik danışma merkezlerine duyulan gereksinimin oldukça fazla olduğuna işaret etmektedir. Son yıllarda psikolojik danışma servislerinin önem kazanmaya başlaması, artık birçok üniversitede psikolojik danışma merkezlerinin kurulmasına katkı sağlamıştır. Bu fırsatlara rağmen üniversite öğrencilerinin psikolojik yardım merkezlerine başvurmakta isteksiz davrandıkları, merkezlere ilişkin olumsuz tutuma sahip oldukları görülmektedir. Bu bağlamda tutumu psikolojik yardım alma tutumunu etkileyen faktörleri belirlemek, tutumu olumlu şekilde değiştirmek için önemli bir faktör olabilir. Bu faktörler içerisinde bireylerin kişilik özelliklerinin önemli bir belirleyici olması olasıdır. Nitekim bireyin özgün ve sürekli olan duygu, düşünce, davranış ve tutumları kendi kişilik özelliklerinin bir sonucudur. Kişilik özelliklerinin yanı sıra, bireylerin sahip olduğu kültürel değerlerin de onların profesyonel yardım alma tutum ve davranışlarının önemli belirleyicisi olması olasıdır. Çünkü kültür, sorunun tanımlanmasında, yardım almaya karar vermede ve baş etme kaynaklarının değerlendirilmesinde önemli rol oynamaktadır. Bireylerin stresle başa çıkma yöntemlerine sahip olmaları da yardım alma tutumları ve davranışları ile ilişkili olması olasıdır. Örneğin bireylerin yaşadıkları sorunlarla baş etme yöntemlerinin onların yardım alma tutumlarını etkilemesi beklenebilir. Bu çalışmanın temel amacı, üniversite öğrencilerinin psikolojik yardım almaya ilişkin tutumlarının doğasını ortaya koymaktır. Bu çerçevede üniversite öğrencilerinin kişilik özellikleri, kültürel özellikleri ve başa çıkma yöntemlerinin onların profesyonel düzeyde psikolojik yardım almaya ilişkin tutumlarını nasıl yordadığı incelenmektedir. Bu amaç çerçevesinde 1284 üniversite öğrencisinden veri toplanmıştır. Verilerin toplanmasında kişisel bilgi formu, Psikolojik Yardım Almaya İlişkin Tutum Ölçeği, IND-COL ölçeği, Temel Kişilik Özellikleri Ölçeği ve Baş Etme Yolları Ölçeği kullanılmıştır.

Araştırmanın amacı doğrultusunda regresyon analizi yapılmıştır. Ölçme araçlarının sıra etkisini kontrol etmek için, ölçme araçlarının farklı biçimde sıralanması ile oluşturulan dört farklı kitapçık katılımcılara rastgele dağıtılmıştır. Regresyon analizinin ön şartlarını sağlayıp sağlamadığı dikkate alınmıştır. $\mathrm{Bu}$ doğrultuda verilerin basıklık çarpıklık değerleri incelenmiş ve normal dağıldığı görülmüştür. Yeterli örneklem büyüklüğüne ilişkin farklı görüşler olmakla birlikte en katı olan görüşe göre katılımc1 sayıs1/yordayıcı değişken oranının 40/1 olması ölçütü dikkate alınmıştır. Bu ölçütlerin yanı sıra çoklu regresyon analizinin oldukça duyarlı olduğu çoklu normal dağılım için Mahalanobis uzaklık değerleri incelenmiş ve otokorelasyon sorunu olmadığını belirlemek için Durbin-Watson değerinin 1-3 arasında olması ölçütü dikkate alınmıştır.

Araştırmanın bulgularında, model 1'de üniversite öğrencilerinin psikolojik yardım almaya ilişkin tutumlarını, kişiliğin boyutlarından olan negatif değerlilik, uyumluluk, yeniliğe açıklık ve sorumluluğun anlamlı düzeyde yordayıcı olduğu; bulunmuştur. Modelin açıklayıcılık gücü dikkate alındığında kişilik boyutlarının birlikte psikolojik yardım alma tutumunun \% 5'ini açıkladığı görülmektedir. Model 2'de kültürün bir boyutu olan toplulukçuluk değişkeni modele eklendiğinde üniversite öğrencilerinin psikolojik yardım alma tutumlarının anlamlı bir yordayıcısı olduğu bulunmuştur Kişiliğin boyutları ve toplulukçuluğun birlikte yardım alma tutumunun yaklaşı \% 6'sını açıkladığı görülmektedir. Model 3'te eklenen başa çıkma stratejilerinden kendini saklama, sosyal destek ve kaçınmanın öğrencilerinin psikolojik yardım alma tutumlarının anlamlı birer yordayıcı olduğu bulunmuştur. Kişilik boyutları, toplulukçuluk ve başa çıkma stratejilerinin boyutları birlikte üniversite öğrencilerinin psikolojik yardım 
alma tutumlarının yaklaşık \% 9'unu açıklamaktadır. Son olarak Model 4'e cinsiyet değişkeni eklenmiş ve öğrencilerin psikolojik yardım alma tutumunun önemli bir yordayıcısı olduğu bulunmuştur. Modelin açıklayıcılık gücüne bakıldığında ise üniversite öğrencilerinin psikolojik yardım alma tutumunun \% 14' ünü açıkladığı görülmektedir.

Uyumluluk kişilik özelliğine sahip olan bireylerin güvenilir, affedici ve başkalarını güvenilir bulma gibi özelliğine sahip olduklarından, ihtiyaç duymaları halinde başkalarının kendilerine yardımcı olacaklarına inandıklarından kendi sorunlarını çözebilmek için yardım almaktan kaçınmayacakları söylenebilir. Sorumlu kişilik özelliği yüksek olan bireylerin planlı, özenli, azimli ve öz farkındalığı yüksek olmak gibi özelliklere sahip olduklarından, sorunu çözmek için bir plan yapacakları, bu kapsamda çeşitli yardım kaynaklarına rahatlıkla başvurabilecekleri düşünülebilir. Yeniliğe açık kişiler meraklı, girişken ve ilgili kişiler olduklarından, ihtiyaç duymaları halinde yardım servislerine başvurabilecekleri ve psikolojik yardım almaya ilişkin daha olumlu tutuma sahip olacakları beklenir. Negatif değerliliği yüksek olan bireylerin durumu kabullenmek, değiştirmek için çaba harcamamak ve sosyal destek aramaktan kaçınmak gibi özelliklere sahip olduklarından, yardım almaktan kaçınacakları ve psikolojik yardım servislerine karşı da olumsuz tutuma sahip olabilecekleri ifade edilebilir.

Toplulukçu kültürün özellikleri olarak, içinde bulunulan grubun fikri, ihtiyaçları ve amaçları; davranışta sosyal normlar ve görevlerin etkisi, grup tarafından paylaşılan ortak inançlar ve grup üyeleriyle iş birliği içerisinde olma isteği vurgulanmaktadır. Bu bağlamda ise iyi insan olmak için ne gerekiyorsa onu yapmaya hazır olmaları, yakın çevresindeki kişilerin fikirlerine önem vermeleri, sosyal destek olarak açıklanabilir. Kendini saklama başa çıkma yöntemini kullanan bireyler sorunlarının farkında olsun ya da olmasınlar, sorunlarını başkalarının fark etmesini, kendilerinin ne kadar zor durumda olduklarının bilinmesini istemez ve bu sebeple sorunlarını başkalarına anlatmaktan kaçınırlar. Sosyal destek alma başa çıkma yöntemi, birey sorun yaşadığında ailesi, akrabası, arkadaşı ya da herhangi yabancı birinden yardım istemesi olarak ifade edilebilir. Bu çerçevede psikolojik yardım servisleri de sosyal destek kapsamında değerlendirilebilir. Kaçınmacı başa çıkma yöntemini kullanan bireyler, soruna doğrudan çözüm aramak yerine ortamdan uzaklaşmak, durumun varlığını yok saymak, farklı etkinliklerle uğraşmak, yemek ya da içmek gibi yöntemleri benimsemektedirler. Bu çerçevede psikolojik yardım servislerine başvurmak ilk olarak sorunlardan kurtulmak için amaçlı ve planlı bir davranış olarak değerlendirilebilecekken, sorunlardan bir kaçış olarak da yorumlanabilir. Kadınların, erkeklere göre daha olumlu tutuma sahip oldukları görülmektedir. Bu durum toplumsal cinsiyet rolleri ile ilişkili görünmektedir. Türkiye'de toplumsal cinsiyet rollerinin oldukça baskın olduğuna işaret etmektedir. Sonuç olarak erkek öğrencilerin duygularını ifade ederek, yardım isteyerek zayıf görünmekten kaçınmak, toplumun kendilerine biçtiği rolleri üstlenmek ve başarı ile sürdürmek için psikolojik danışma servislerine gitmekten kaçındıkları ve yardım almaya ilişkin de olumsuz tutuma sahip oldukları söylenebilir. 